\title{
A musing I would like to have shared with Gwendolyn MacEwen
}

\author{
Penn Kemp
}

\section{Rêverie que j'aurais aimé partager avec Gwendolyn MacEwen}

\begin{abstract}
Penn Kemp décrit la vision qu'elle eut de Gwen MacEwen justeaprès la mort de cette dernière et explique comment cette auteure en est venue à incarner pour elle la notion d'anima. Elle dépeint l'anima comme un archétype et un 'espace seuil', un psychopompequi guidel'esprit chercheur dans son labyrinthe, maisaussi comme'desétats intermédiaires', 'un arc, qui attend pareil à un témoin'. En essayant d'exprimer les étapes corporelles pré-verbales de la connaissance, Kemp pose les premiers jalons d'une poétique du 'corps langagier'.
\end{abstract}

When I first heard of Gwendolyn's death, her image in my mind exploded into light. I felt her dancing, free. All night I heard her voice in my head, speaking poetry, too fast to be recorded. I felt her expand into the spaciousness of Egypt. She beckoned me to join her, joyous, radiant with inner knowing and new certainty. But the next day, she appeared again in my mind, wandering, confused, looking for the way back into her body. 'Look to the Light,' I enjoined her in the Tibetan tradition. 'Do not let your attention wander.' For the next four days, I experienced her presence. It was as if she wanted to speak through me. It was as if she wanted me to join her.

Who knows what is real? I told her she had indeed died, and that the way for her now was toward the light. She could not stay hovering here. I was too busy to write down even the lines I heard. Despite a shame of being unkind, I baulked at being a scribe, at sharing my psychic space. She understood, however; her face seemed to clear in realization. Nodding her head, she moved away toward the unknown that loomed behind her. At the darkest time of the year, it was a moment of choice. I had to choose to separate myself from $G$ wen, from 
her death. I had to choose not to succumb to the mythology of the poet doomed by society. The despair was real. Though I could not know if Gwen were in touch or not, her death was certain. So I gave my despair to Gwen, let her use that energy to move toward the light. It was as if she by her death had died for or instead of me, poets, women, humanity.

Since then, she has appeared rarely, from a distance, not looking at me but intent on her own path. I light a candle for her nonetheless. Now that she is no longer embodied, Gwen has become entwined for me with the notion of Anima. She has been lifted into poet and muse. She has settled into the elements. Her green eyes shine from the depths. Her voice. She has moved into another zone of consciousness, away from the bleariness she hated. She has merged into mystery though her image remains distinct before me. And as Anima she asks me to choose life.

How do I locate the threshold space where Gwen now seems to live? Images of Anima dance before me as I write. As archetype, Anima is Hestia, guardian of the hearth. Hermes protects her: the tenemos, the numinal. She is best represented as fish, as eel, something that could so easily slip out of hand back into her natural element, water. Melusina. Mermaid. The sirens. Ancestral voice. The reptilean brain. Something that resists handling, resists conscious knowing. But is herself in touch with her element, moving through water, pervasive, becoming her element. She perches on a rock, basking in the sun and ready, at any sudden movement in her peripheral vision, to slip back into water, home, safety. She is the amphibian ability to be in two places at once, half in the water and half out.

Anima appears at moments of transition, moments of crisis and shock. Her presence is a shimmering web I have come to identify as a certain numinosity of change, muted colours and forms. Anima is what James Hillman calls soul, the low-lying vale, swamp and water. For me, she is shape-changer, the shadow between seasons, between polarities. She is dawn and dusk. All subtlety and evasion, her effect is indirect, caught on the periphery of vision, a dream flicker. Her element is water and a play of light. My image of Anima implies animal, plant, mineral, inclusive of all the other kingdoms, queendoms. But her essence is fire, the phosphorescent spark in the deep sea. And a certain fragrance that can't be located. Her power is as great as it is 


\section{A Musing $\cdot 51$}

unnoticed and pervasive. It is in the network of synchronicity that hovers below and around the working focus of the mind.

I learn to distinguish between Gwen and her image, between the personal and the archetypal, between self and other. The Anima merges past, present and future, blurring distinctions between personalities. She is commonality, linking human feeling to the archetypal world. She is larger than any one person, even one who has identified herself with the archetype as I believe Gwen did. She chose to embody that realm in her writing. Through the Anima flows the sense of destiny with which Gwen was allied.

I take it for granted that the mind creates its own version of the past with each selection of personal history it chooses to highlight. I believe we are in the process of inventing our own history as well as our future by the way in which we hold the only moment of power that we have, the present moment. The present is the time of choice, and the possibility of change. So it is well to be mindful of how I choose in aligning my conscious intention to the larger sense of destiny Anima offers. To follow each clue through the labyrinth, beginning from the entrance underground, I cannot identify with the labyrinth, with the Anima. I need to discriminate between threads of familiar thoughts that loop in circles, loose ends that need tying, and a line of inquiry that will lead me into something larger than where I began. Anima has been teaching me to spin.

I have met her before, at key points in my life, in dream. She is prompter, pushing and pulling consciousness on, up, out. It is easier to define what she is not or to laden her with adjectives, the shifting veils she surrounds herself with, than to name her. She is no mirror to me. She is completely other, though we know each other inside out. I do not know whether she knows everything that has happened or will happen. I do know she carries the weight of possibilities, of probabilities, wafting like feathers at peripheral vision, for me to grasp as I can. She leaves it to me to figure out how to become what she envisions. Anima holds up a thousand mirrors to demonstrate that what we concentrate on we become. Each mirror is a possibility which I could enact if I chose.

She is the emerging impulse of intention, the Intention not just of my conscious mind, but larger and shadowy, unknown and perhaps unknowable. I believe she offers the plan of my life: the blueprint I 
carried before conception. And so my perspective of events, when aligned with hers, is suddenly and subtly vast with possibility. Anima leaves it entirely to me as to whether I pick up the skeins of Intention. She does not, like Ariadne, offer one connective thread that would lead me to the plot-line that would make sense of my life, but a thousand multi-coloured strands that I must braid and weave myself. We are co-creators. As psychopomp, she is flippant, a raised eyebrow, a shrug of the shoulder. What's it to her whether I perceive her gifts as schemes to entrap me or a schema to elucidate? She is Godiva, earth goddess, not a White Knight: she entrances; she does not rescue. She has no need to teach, no need of me. But she is delighted to dance, to play, to come into my consciousness as co-conspirator, breathing with me into more abundant life.

Where? In the space of the moment as it is lived. Anima is multidirectional and so it is difficult to locate her, though she herself is always precisely situated in the particularity of image, in eidolon. She is the one green turtle in swamp; she is the white bird perched on the willow tree on the island across the bay. She beckons me with flipper, a wing, a paw, a veiled arm. When she appears, I pay attention, as to a signpost. My work is to acknowledge her presence throughout the periods of transition in my life. To pay homage to her as the power of change. My only choice is to flow with her, or to resist: and the price of resistance is a stiff neck, a paralyzed body. I never know the price of change, but I am learning to trust, to leap into the new. My choice then is when, and how, not why, not even where, for where exactly I am leaping is the mystery and the challenge Anima posits.

The risk is large, because I am writing into empty space, without knowing the parameters of the essential question I want to ask. Anima as guide demands acute discrimination from me, because she appears to have no regard for what I consider to be my welfare. I have learned that the archetype in her push for evolution has no concern for human frailty. And I am afraid of delving into old pain, old stories, without coming to resolution. I am afraid of being bogged down in my own morass. But I trust that by the end of the essay, the question, if not the realm of possible 'answers,' will be clear. I want a mélange of all my realities in the text, dreams, fantasies, physical symptoms and their emotional equivalents, calls and inquiries down the long halls of the mind.

The word clue seems to be the clue: connective tissue. Ways in and 
out. All the incidents reflect the same metaphor. I recognize my 'signature,' the same result no matter what one does. No matter how far I look back, to birth and beyond into 'past' lives: the longer the retrospective view, the more consistent, more detailed the imprint. I do not easily translate visual images into consciousness: they prefer to stay as they are, as direct knowing without need of words. And yet my profound belief is in the possibility of words as translation from that source. And as communication. I seem to be often on the brink of hearing, of saying something really important that I can't quite hear. The writing is a moving toward, away from that sense of apocalypse. Because at that place, exstasis, there are no words. Yet. All I can record is the process, not the main event.

If I identify with Anima as archetype, I am lost to my humanity. I am a receiver of images from the deep swamp. I am not in charge of my life. And yet I am managing to live from my right brain almost entirely. What is the process by which I understand, in this mode? How do I cover up? I notice that if I try to think sequentially, the ideas jam and I cannot remember. How do I block myself? I forget to move if I am stuck, if the swamp mud pulls me down into torpor. I forget to look for bridges, other doors, other ways. I tend to stay with the 'problem,' staring it in the face, till it is incredibly magnified and I am reduced. I become toad, double-lidded.

Choices, even at death, at the threshold of the new. I am restless, not yet born and not yet ready. Still in the birth canal, shedding the old skin. I need less sleep. That scares me, I love those hours of unconsciousness. Instead of a joy, the extra time is a burden: more hours to fill, more I have to do. Responsibility. But wouldn't I rather have that time for jogging or doing tai chi or meditating? Can I grow into that largeness? The greatest growth is in the dark. The flow of necessity, the patience of gestation. Always, discrimination is my necessity, without blame. And that discriminating sense comes from my whole body/mind; it is not isolated mental judgement. I perceive that knowing as a kind of blue rippling felt along the torso. The participles I use to describe it indicate its quality of movement: it is active, energy perceiving itself.

But in that recognition of energy to energy, inner and outer, there is a moment of stasis, a moment of naming which catches the quality of the energy perceived. At last I remember to ask Anima the question by which Parsival healed the Fisher King of the Graal: 'What is your 
name?' Immediately behind that question are others: 'Whom do you serve? What matters? What is your function? What is your meaning for me here, now? What do you want? What do you need?'

The question is never why: why leads us back into the morass of historicity, the dead ends of cause upon cause. The question is not what, because Anima does not seem to be able to articulate a particular zone of consciousness where she is at for me. She lives between the elements, as the haze of water aired, the steam of water fired, the mud of water earthed. She is always in between states, hovering, bending back, arching forward. She is reflection, involved and aloof. She is the arc, waiting as a witness waits. I witness her witnessing me.

What difference is to be named? The naming alters perception and adds to discrimination. As soon as I name, I am also not naming. The Anima would claim that it is a larger existential task in life to say with whom she is allied than with whom she is not aligned. To escape categorizations, it is easier not to name, to let the name go. But we live in a linguistic community, through the power/sign of naming. In changing a name, our world view shifts.

Speech, 'la parole' is feminine, but words, 'le verbe,' are not. The ear is feminine, the shell, the curve of life emerging from the ocean. The cerebral-spinal fluid holds all our pre-conscious, pre-conception memories. Through the hydraulic flow and balance, we can access these memories of the etheric body and of the soul.I listen to the sound of the sea-shell, to the voice of Anima. And recognize her song as my own, my deepest note. One tone is sounded in and through each of our actions. Discovering my tone is discovering my self. Perhaps only that one tone can come to create, out of the profound silence. My tone is my destiny.

And so Anima answers. There is no assignment of value in this naming, but a recognition of different functions, each proper in its place. Anima is neither positive or negative, female or male: $s /$ he IS, living in the verb of all possible existence. If Anima can tell me her name, she is telling me her intent. And that intent, I believe, must ultimately be for our common good, for harmony and wholeness, despite her methodology. If I need to be swamped before she has my attention, I am swamped. Parts of me, fear and doubt and righteousness, need to die before I learn her name, her witnessing. I choose to allow them to die. Or more correctly, to find their true functions: fear in awareness, doubt in discrimination and righteousness in knowing. 


\section{A Musing $\cdot 55$}

From the pit of emptiness, out of the swamp, I find something, a fullness, a shift of perception that allows me to see the process as a reclamation of my full being. That something is the simple human choice to live. At one point, I thought I had no alternative but to die. And certainly I was winding down, as if preparing. But at the time of greatest despair, physical and emotional, something in me shifts. The shift can occur at the point of most helplessness, when you either shift or you don't. I give myself permission to make the shift. The swamp lightens into turquoise sea, through which I am free to swim. I feel myself claiming life, realizing that I could pull myself up out of morass, finding the desire, the grace of illumination in the depth of what had seemed complete darkness. Nothing has changed but a spark of awareness that Anima has lit in me, in the murky swamp that teems with life, with possibility. That spark of yang at the centre of yin is the essence of Anima.

I thought I was going to talk about Gwen's death. About the metaphor of splitting apart/open: how even the choice of adverbs, apart or open, marks a gap in attitude toward the process. About boundary. About the process of time. About memory, the sadness of forgetting, of where the thoughts go that were once heard as truths and have to be learned again and again. About trusting the process of the body. About learning its language, both in dream and in physical manifestation. About paying attention. About. Those are the markings in the appendices, the lines I have read or written, assimilated as truths.

Instead I have not talked about. I have chosen direct cognition, through dream, reflection and symptoms. I have been interested in developing a language for the body so that I can be continually more aware of its processes. But that language is direct and spatial, nonlinear. Its form is that of a poem. I have become more aware of various forms of energies as I write, but they are kinaesthetic and so by nature impossible to describe in words, except by analogy. The metaphor dominant is that of the figure eight, on the centre of which I sit perched, able to look inside or out. As if I have put on and become a clown's nose and am sitting on the edge of skin.

The impact of my life is in the movement from the personal into something larger. I can step into transcendence, putting on the clown's nose. I am feeling large, realizing I could be with all my loved ones, in spirit presence. No more projected love, projected power to be lost in the void between self and image. A surge of will/intent from 
the unconscious is now available whenever I place myself in the right psychic position, to speed up my thyroid with the joy of all I want to do. To enter into the left brain like a laser, clearing the cobwebs so I can think and plan logically. I have just completed a manuscript, calling it 'Wise Cracking the C'Ode of the Lunar Plexus.' The lunar plexus I invented, have even positioned in the body. Its horns tip the two adrenal glands. The crescent is in the back saddle. Now that it's been located, I'm sure scientists will discover its actuality and purpose. I'll leave that up to them.

Winter Solstice, the time of the Fool, is complete; we have entered the depths once more on the seasonal round, and begin to emerge into the light of new consciousness. The deepest mystery for me as a human being is that we are earth's creatures, following her rounds. If we put ourselves in accordance with the seasons, we can move appropriately with the energy of the time, in synch. We can at this point in time, catch the small flare of light at the very centre of yin, and bring that yang of consciousness into our daily living. I learn to pay attention to the life pull of the Anima, not the death pull.

The relation between the personal and the world is so intriguing. As poets we receive the energy of the times, are antennae of the race. But we can be, have so often been, swept away by the excitement. Our role may simply be the leap of the first lemmings off the cliff, thinking ourselves individuals, not knowing that the rest of the pack are following on our heels. This is the time for discrimination, perhaps for the middle way of Buddhism. Yet what does the cliff represent? I think of the Holy Fool in the Tarot, stepping into the void. I think of Gwen, stepping into the void as we all must.

Each new life is preceded by a little death, and who is to know the outcome? The death is dramatically real enough at the time of transition. From the other side, it is all too easy to look back benignly and complacently on our poor benighted former self, 'I knew it would work out allalong.' That's even a technique to use, during the birthing: to shift perspective and visualize the scene from a future vantage point. Is our experience just the result of attitude, a shift of perception to embrace a new and wider paradigm? Why does the knowledge of that power create fear in me, rather than joy at the possibility? Too much responsibility? What in experience is admissible? What demonstrates a new life becoming? What words make possible that which comes into being? What transforms knowledge? Some new way of 
using my intelligence, beyond the personal. An acceptance of facts. But I am not blocked from other choices, opportunities, outcomes by emotional reaction to decisions, however arbitrary they may seem.

In meditation, early this morning, the Anima appeared, shimmering, ready to talk. I must sharpen my hearing. Her voice vibrated out as if from under water, muted by psychic distance. Sound waves of colour and texture, not easily defined but unmistakable as felt presence. I was enfolded, though she herself remained distant. I could see her lips move, intending to communicate with me. But I could not make out her meaning, even though her entire body represented something I could almost comprehend, but only as totality, not as specifics.

The Anima moves out of linguistic speech into pictogram, into the languaging body. I can only meet her in terms of her own language, the sign. However, that will stretch my own sense of what can be articulated. Already there is possibility. I sense in her a middle ground between personal introversion and continental spaciousness, the experience of the Void in Egypt. Anima thus becomes a vehicle for transformation, an alchemical vessel. The work must be done alone, by the individual.

There is no ending in terms of living on the threshold. For years I worried about seeking out the light, because I thought that in so doing I would be unbalanced. I kept remembering 'the line drawn by its own weight into a circle,' the law of enantiodromia, of opposites. And I did not want to deny the dark, a space I was familiar with, as woman and as poet. This was the richness I recognized in Gwendolyn. I understand poetry to be just another abstraction from our perceptions. But it is visceral, and so can transmit the reality of our experience in thesame way music can, the words as vehicles for those who have ears to hear. An embodied poetics.

I meant to call Gwendolyn the day she died: I didn't because I was busy planning a trip to Egypt. We shared a love of that place as if it were a zone of consciousness that we could never quite live in. A mythology of source, a knowledge embodied in ancient temples. I hope she is there now; I hope to return. 